Pesq. Vet. Bras. 36(9):857-863, setembro 2016 DOI: 10.1590/S0100-736X2016000900011

\title{
Blood pressure and renal injury in dogs with visceral leishmaniasis ${ }^{1}$
}

\begin{abstract}
Marlos G. Sousa ${ }^{2 *}$, Amanda B.G. Lima ${ }^{3}$, Cristiane R.A. Araújo ${ }^{3}$, Vinícius B.C. Silva², Adriano T. Ramos ${ }^{4}$, Gisele F. Machado ${ }^{5}$, Guilherme D. Melo ${ }^{5}$ and Roberta Carareto ${ }^{3}$

ABSTRACT.- Sousa M.G., Lima A.B.G., Araújo C.R.A., Silva V.B.C., Ramos A.T., Machado G.F., Melo G.D. \& Carareto R. 2016. Blood pressure and renal injury in dogs with visceral leishmaniasis. Pesquisa Veterinária Brasileira 36(9):857-863. Departamento de Medicina Veterinária, Universidade Federal do Paraná (UFPR), Rua dos Funcionários 1540, Cabral, Curitiba, PR 80035-050, Brazil. E-mail: marlos98@ufpr.br

Systemic hypertension is known to be a common consequence of chronic renal disease, which is frequently diagnosed in dogs with visceral leishmaniasis. Although many veterinary investigations have looked at the renal injury caused by Leishmania spp., the role played by this complication in the development of arterial hypertension documented in some animals with visceral leishmaniasis is not completely understood. In this study, 18 adult dogs with naturally-occurring visceral leishmaniasis and varying clinical signs underwent an indirect blood pressure measurement. Also, sera and spot urine were used for laboratory tests. The median systolic blood pressure was $135.2 \mathrm{mmHg}(95 \%$ confidence interval: 128.5-147.7), median mean arterial pressure was $105.8 \mathrm{mmHg}(98.3-110.4)$, and median diastolic arterial pressure was $88.5 \mathrm{mmHg}(77.8-92.5)$. No differences existed between asymptomatic and symptomatic animals regarding arterial pressure, and no correlations were documented between blood pressure and serum creatinine, blood urea, urine protein-to-creatinine ratio, urine specific gravity, and the fractional excretion of sodium and potassium. Although an association between hypertension and the identification of inflammation on histopathology could not be demonstrated in hypertensive animals, the assessment of kidney samples from 12 dogs indicated mild inflammation with a lymphoplasmacytic infiltrate $(6 / 12)$, moderate inflammation with multifocal lymphoplasmacytic and histiocytic infiltrates (3/12), and multifocal degeneration and protein casts $(2 / 12)$. Anti-Leishmania spp. immunohistochemistry assays stained the renal epithelium in $2 / 12$ of the animals. Even though mild systemic hypertension was documented in a small subset of animals, no relationship between the severity of clinical signs and hypertension could be anticipated.
\end{abstract}

INDEX TERMS: Blood pressure, kidney, dog, leishmaniasis, parasitic disease, glomerulopathy, proteinuria, hypertension.

\footnotetext{
${ }^{1}$ Received on August 7, 2015.

Accepted for publication on May 8, 2016.

${ }^{2}$ Universidade Federal do Paraná (UFPR), Rua dos Funcionários 1540, Bairro Cabral, Curitiba, PR 80035-050, Brazil. *Corresponding author: marlos98@ufpr.br

${ }^{3}$ Escola de Medicina Veterinária e Zootecnia (EMVZ), Universidade Federal do Tocantins (UFT), BR-153 Km 112, Campus EMVZ, Araguaína, TO 77800-970, Brazil.

${ }^{4}$ Universidade Federal de Santa Catarina (UFSC), Rodovia Ulysses Gaboardi Km 3, Campus UFSC, Curitibanos, SC 89520-000, Brazil.

${ }^{5}$ Departamento de Clínica, Cirurgia e Reprodução Animal, Universidade Estadual Paulista (Unesp), Rua Clóvis Pestana 793, Ipanema, Araçatuba, SP 16050-680, Brazil.
}

RESUMO.- [Pressão sanguínea e lesão renal em cães com leishmaniose visceral.] A hipertensão sistêmica é reconhecida como uma consequência comum da doença renal crônica, cujo diagnóstico é frequente em cães com leishmaniose visceral. Embora muitas pesquisas veterinárias tenham investigado a lesão renal causada pela Leishmania spp., o papel dessa complicação no desenvolvimento da hipertensão arterial documentada em alguns animais com leishmaniose visceral ainda não é completamente compreendido. Neste estudo, 18 cães adultos com diagnóstico de leishmaniose visceral e sinais clínicos variáveis foram submetidos à avaliação indireta da pressão arterial. Além 
disso, foram coletados soro e urina para análises laboratoriais. As medianas das pressões arteriais sistólica, média e diastólica foram 135,2mmHg (intervalo de confiança de 95\%: 128,5-147,7), 105,8mmHg $(98,3-110,4)$ e $88,5 \mathrm{mmHg}$ $(77,8-92,5)$, respectivamente. Não foram constatadas diferenças entre os cães assintomáticos e sintomáticos em relação à pressão arterial, assim como não houve correlação entre a pressão arterial e a creatinina e uréia séricas, relação proteína-creatinina urinária, densidade urinária e excreção fracionada de sódio e potássio. Embora não tenha sido evidenciada associação entre hipertensão arterial e inflamação do tecido renal à histopatologia, a avaliação das amostras oriundas de 12 cães indicou inflamação leve, com infiltrado linfoplasmocitário (6/12), inflamação moderada com infiltrados linfoplasmocitário e histiocítico multifocais (3/12), além de degeneração multifocal e cilindros protéicos (2/12). Ensaios imunoistoquímicos anti-Leishmania spp. marcaram o epitélio renal em 2/12 animais. Apesar de hipertensão leve ter sido documentada em uma pequena parcela dos cães estudados, não se evidenciou relação entre a severidade dos sinais clínicos e o desenvolvimento de hipertensão arterial.

TERMOS DE INDEXAÇÃO: Pressão sanguínea, rim, cães, leishmaniose visceral, doença parasitária, doença renal, glomerulopatia, proteinúria, hipertensão.

\section{INTRODUCTION}

Leishmaniasis is a potentially fatal disease occurring in people and both domestic and wild animals. It is caused by a protozoa belonging to the genus Leishmania, which is distributed throughout subtropical and tropical areas, although it may be found even in temperate zones. Despite its insidious progression, systemic consequences may arise and ultimately lead to an expressive death rate in infected untreated subjects (Baneth et al. 2008).

Owing to the multisystemic nature of leishmaniasis, several clinical signs may be observed. Emaciation, muscle atrophy, lymph nodes enlargement, ocular alterations, cutaneous desquamation, and either exfoliative, ulcerative or pustular dermatitis are particularly common in dogs with visceral leishmaniasis. The pathophysiology of these manifestations may include a granulomatous inflammatory reaction associated with amastigotes of Leishmania spp. within macrophages (Ciaramella et al. 1997, Koutinas et al. 1999, Solano-Gallego et al. 2004, Baneth et al. 2008). It is believed that kidneys are damaged in nearly all dogs with visceral leishmaniasis. Renal injury is ascribed to either interstitial nephritis or the deposition of the parasite antigen at the glomeruli, which might lead to glomerulonephritis, tubulointerstitial nephritis, and amyloidosis with renal failure. In a study that included 55 positive dogs, glomerulonephritis was observed in $100 \%$ of the animals, although 13 were completely asymptomatic (Costa et al. 2003, Baneth et al. 2008). Nonetheless, it is well known that the detection of azotemia only becomes evident when the majority of nephrons are injured, which unfortunately happens to occur later in the course of the disease (Nieto et al. 1992, Koutinas et al. 1999).
Arterial pressure is maintained by the complex equilibrium of pressor factors, which include the sympathetic nervous system, the renin-angiotensin-aldosterone system, and endothelin, and depressor factors, comprising the parasympathetic nervous system, nitric oxide, prostacyclin, and natriuretic peptides (Dukes, 1992). Alterations in blood pressure occur when any imbalance exists in pressor and depressor factors (Krieger et al. 1996).

Considering the wide array of changes in renal physiology occurring in dogs with visceral leishmaniasis and the key role played by the kidneys in blood pressure regulation, the authors hypothesized that the more severe the renal lesions, the greater the elevation of arterial pressure. Therefore, this study was conceived to investigate the blood pressure in dogs with naturally-occurring visceral leishmaniasis in accordance with the severity of clinical signs and the actual association between renal injuries and the development of arterial hypertension.

\section{MATERIALS AND METHODS}

Animals. Eighteen adult dogs $(11.0 \pm 7.9 \mathrm{~kg}, 9$ females $)$ were recruited for this prospective cross-sectional observational study. Pure and mixed-breed animals were represented. The dogs presented varying clinical signs, such as emaciation, lymphadenomegaly, skin lesions, ocular alterations, muscle atrophy, and onicogryphosis, but some of them were completely asymptomatic. Inclusion criteria included the animal testing positive in two serological tests for Leishmania spp. (IIFA and ELISA) plus the identification of amastigote forms of Leishmania spp. in lymph node aspirates. Exclusion criteria included the dogs testing positive for any other condition, including ehrlichiosis, babesiosis, toxoplasmosis, leptospirosis, and Chagas disease, as well as the owners not agreeing to voluntarily participate in the study, which was conducted in a veterinary teaching facility.

Once the animals met all inclusion and exclusion criteria, they were categorized in three groups according to their presenting clinical signs. In this regard, four animals with no clinical signs were included in Group I (asymptomatic); six dogs which presented at least two clinical signs were included in Group II (oligosymptomatic); and finally eight dogs with more than two clinical signs composed Group III (polysymptomatic). The study was entirely conducted in accordance with the guidelines outlined in the National Institutes of Health Guide for the Care and Use of Laboratory Animals and was approved by the institutional animal experimentation ethical committee (protocol 10/11621).

Assessment of arterial blood pressure. To measure arterial pressure the animals were maintained in right lateral recumbency, with the cuff positioned around the distal left humerus, next to the elbow. An oscillometric non-invasive blood pressure equipment was used, providing five approximate results of systolic, mean, and diastolic blood pressures. The ideal width and length of the cuff was determined as $40 \%$ and 1.5 -fold, respectively, of each animal's limb circumference.

Laboratory assessment of renal injury. Renal injury was assessed using several ancillary methods, including the fraction excretion (FE) of sodium and potassium, serum creatinine and urea, urine specific gravity, as well as the urine protein-to-creatinine ratio (UPC). Urine specific gravity (USG) was determined by refractometry. UPC was documented as the ratio between urine protein and urine creatinine, and the FE of electrolytes was determined using the following equation: $\mathrm{FE}=$ [(Urine electrolyte . Plasma creatinine) / (Urine creatinine $\cdot$ Plasma electrolyte)] 100. 
Histopathology and immunohistochemistry. Renal tissue samples that included both the cortex and medulla were used for histopathology. Samples were fixed in 10\% neutral-buffered formalin. After 24 hours the tissues were transferred into $70 \%$ ethanol prior to processing into paraffin. Later, the samples were embedded in paraffin, sectioned at $5 \mu \mathrm{m}$, and stained with hematoxylin and eosin staining, and Masson's trichrome. The kidney of dogs with leishmaniasis was compared with that of healthy dogs and lesions semi-quantitatively scored for injuries on a scale of 0 (absent), 1 (mild, small focal lesions), 2 (moderate, multifocal or focally extensive lesions), and 3 (severe, affecting most areas).

Also, immunohistochemistry assays were performed as described by Tarufi et al. (2004), using antibodies targeting Leishmania spp. within the renal structures. Briefly, deparaffinized samples were hydrated and incubated in $2 \%$ hydrogen peroxide 10 (v/v) in 0.01 M PBS, pH 6.0, followed by incubation with $10 \%$ skimmed milk aiming at blocking endogenous peroxidase activity and nonspecific immunoglobulin absorption to tissues, respectively. Samples were then incubated in humid chamber with heterologous hyperimmune canine serum for $18 \mathrm{~h}$ at $4^{\circ} \mathrm{C}$. After washing in PBS, the slides were incubated with biotinylated side antibody (DAKO), washed in PBS, and incubated with streptavidin-peroxidase complex (DAKO) for 45 minutes at $37^{\circ} \mathrm{C}$. Finally, the reaction was developed with 3-amino-9-ethylcarbazole (AEC, DAKO), counter-stained with Mayer's hematoxylin, rinsed in distilled water and mounted in aqueous medium.

Statistics. The data was tested for normality using D'Agostino \& Pearson omnibus normality test. Either an analysis of variance or Kruskal-Wallis test was used to check for differences between groups. Also, chi-square was calculated to verify whether an association existed between systolic arterial hypertension ( $>140$ $\mathrm{mmHg}$ ) and renal inflammation detected on histopathology. All analyses were performed using the software Graphpad Prism v.3.00, with the probability $<0.05$ considered to be statistically significant.

\section{RESULTS}

Blood pressure data (Table 1) was not normally distributed, but sera and urine parameters were. Considering all animals in the study, the median systolic blood pressure was $135.2 \mathrm{mmHg}$ (95\% confidence interval: 128.5147.7), median mean arterial pressure was $105.8 \mathrm{mmHg}$ (98.3-110.4), and median diastolic arterial pressure was $88.5 \mathrm{mmHg}$ (77.8-92.5). Only 38.9\% (7/18) of the dogs had a systolic arterial pressure (SAP) higher than $140 \mathrm{mmHg}$, which was considered as the cut-off for systemic hypertension in this investigation. However, no differences existed between groups regarding blood pressure, despite there was a trend of increase in SAP for the symptomatic groups. Only $27.8 \%(5 / 18)$ of the dogs were azotemic (serum creatinine $>1.5 \mathrm{mg} / \mathrm{dL})$, although only $5.5 \%(1 / 18)$ concurrently had SAP $>140 \mathrm{mmHg}$. Nonetheless, $66.7 \%(12 / 18)$ of the animals had a UPC $>0.5$, while $33.3 \%(6 / 18)$ were hypertensive as well.

Correlations were not documented between blood pressure data and serum creatinine (mean \pm standard deviation: $1.1 \pm 0.4 \mathrm{mg} / \mathrm{dL})$, blood urea $(39.4 \pm 21.5 \mathrm{mg} / \mathrm{dL})$, urine protein-to-creatinine ratio (1.0 00.9$)$, urine specific gravity $(1.023 \pm 0.013)$, and the fractional excretion of sodium $(1.0 \pm 0.4 \%)$ and potassium $(9.8 \pm 4.9 \%)$. Table 2 gives the results for each group individually. Differences between groups were only found to exist for the $\mathrm{FE}$ of $\mathrm{Na}^{+}$and $\mathrm{K}^{+}$.

Histopathology was performed in $66.7 \%(12 / 18)$ of the dogs (Fig.1). A mild inflammation with a lymphoplasmacytic infiltrate was documented in $50 \%(6 / 12)$ of the samples, whereas $25 \%(3 / 12)$ showed moderate inflammation with multifocal lymphoplasmacytic and histiocytic infiltrates. Multifocal degeneration and protein casts were

Table 1. Medians and $95 \%$ confidence intervals of blood pressure data obtained non-invasively in dogs $(\mathrm{n}=18)$ with naturally-occurring visceral leishmaniasis

\begin{tabular}{lcccc}
\hline $\begin{array}{l}\text { Arterial pressure } \\
\text { (mmHg) }\end{array}$ & $\begin{array}{c}\text { Group I } \\
\text { (asymptomatic) }\end{array}$ & $\begin{array}{c}\text { Group II } \\
\text { (oligosymptomatic) }\end{array}$ & $\begin{array}{c}\text { Group III } \\
\text { (polysymptomatic) }\end{array}$ & $\begin{array}{c}\text { P } \\
\text { (Kruskal-Wallis) }\end{array}$ \\
\hline Systolic & 128.2 & 130.3 & 144.4 & 0.0679 \\
Mean & (119.4 to 138.3$)$ & $(118.4$ to 140.4$)$ & $(129.4$ to 169.0$)$ & \\
& 104.4 & 100.7 & 107.0 & 0.6689 \\
Diastolic & (90.4 to 116.6$)$ & $(87.3$ to 114.7$)$ & $(95.7$ to 118.8$)$ & \\
& 90.3 & 78.9 & 90.0 & 0.4221 \\
& (71.0 to 102.1$)$ & $(64.0$ to 95.7$)$ & (74.2 to 102.7$)$ &
\end{tabular}

Table 2. Means and standard deviations of blood and urine data obtained in dogs $(n=18)$ with naturally-occurring visceral leishmaniasis

\begin{tabular}{lcccc}
\hline $\begin{array}{l}\text { Parameter } \\
\text { (normal rage) }\end{array}$ & $\begin{array}{c}\text { Group I } \\
\text { (asymptomatic) }\end{array}$ & $\begin{array}{c}\text { Group II } \\
\text { (oligosymptomatic) }\end{array}$ & $\begin{array}{c}\text { Group III } \\
\text { (polysymptomatic) }\end{array}$ & $\begin{array}{c}\text { P } \\
\text { (Anova) }\end{array}$ \\
\hline $\begin{array}{l}\text { Serum creatinine } \\
(0.4 \text { to } 1.5 \mathrm{mg} / \mathrm{dL})\end{array}$ & $1.05 \pm 0.53$ & $1.25 \pm 0.36$ & $1.35 \pm 0.46$ & 0.5578 \\
$\begin{array}{l}\text { Serum urea } \\
(15 \text { to } 55 \mathrm{mg} / \mathrm{dL})\end{array}$ & $37.35 \pm 22.31$ & $45.68 \pm 23.83$ & $52.14 \pm 20.31$ & 0.5535 \\
$\begin{array}{l}\text { Urine protein-to-creatinine } \\
\text { ratio }(<0.5)\end{array}$ & $0.58 \pm 0.41$ & $0.97 \pm 0,61$ & $2.16 \pm 1.60$ & 0.0738 \\
$\begin{array}{l}\text { Urine specific gravity } \\
(1.015 \text { to } 1.045)\end{array}$ & $1.024 \pm 0.015$ & $1.021 \pm 0.014$ & $1.025 \pm 0.012$ & 0.8318 \\
$\begin{array}{c}\text { Fraction excretion Na+ } \\
(<1 \%)\end{array}$ & $0.70 \pm 0.08^{\mathrm{A}}$ & $1.25 \pm 0.50^{\mathrm{AB}}$ & $2.19 \pm 1.28^{\mathrm{B}}$ & 0.0429 \\
$\begin{array}{l}\text { Fraction excretion K+ } \\
(<24 \%)\end{array}$ & $6.30 \pm 1.12^{\mathrm{A}}$ & $11.07 \pm 5.95^{\mathrm{A}}$ & $17.76 \pm 3.68^{\mathrm{B}}$ & 0.0015 \\
\hline
\end{tabular}

Different uppercase letters indicate significant differences $(\mathrm{p}<0.05)$ between groups at the post hoc Tukey test. 
Fig.1. (A) Renal medulla exhibiting intratubular hyaline casts. Hematoxylin and eosin (HE), obj.10x. (B) Hyaline casts and a focus of lymphoplasmacytic infiltrate observed within the renal medulla. HE, obj.40x. (C) Cortical area showing multiple foci of lymphoplasmacytic and histiocytic infiltrates. HE, obj.10x. (D) Lymphoplasmacytic and histiocytic infiltrates obliterating the renal parenchyma. HE, obj.40x; (E) Foci of connective tissue within the renal parenchyma. Masson's Trichrome, obj.10x (F) Mild thickening of both the glomerular basement membrane and Bowman's capsule. Masson's Trichrome, obj.40x.
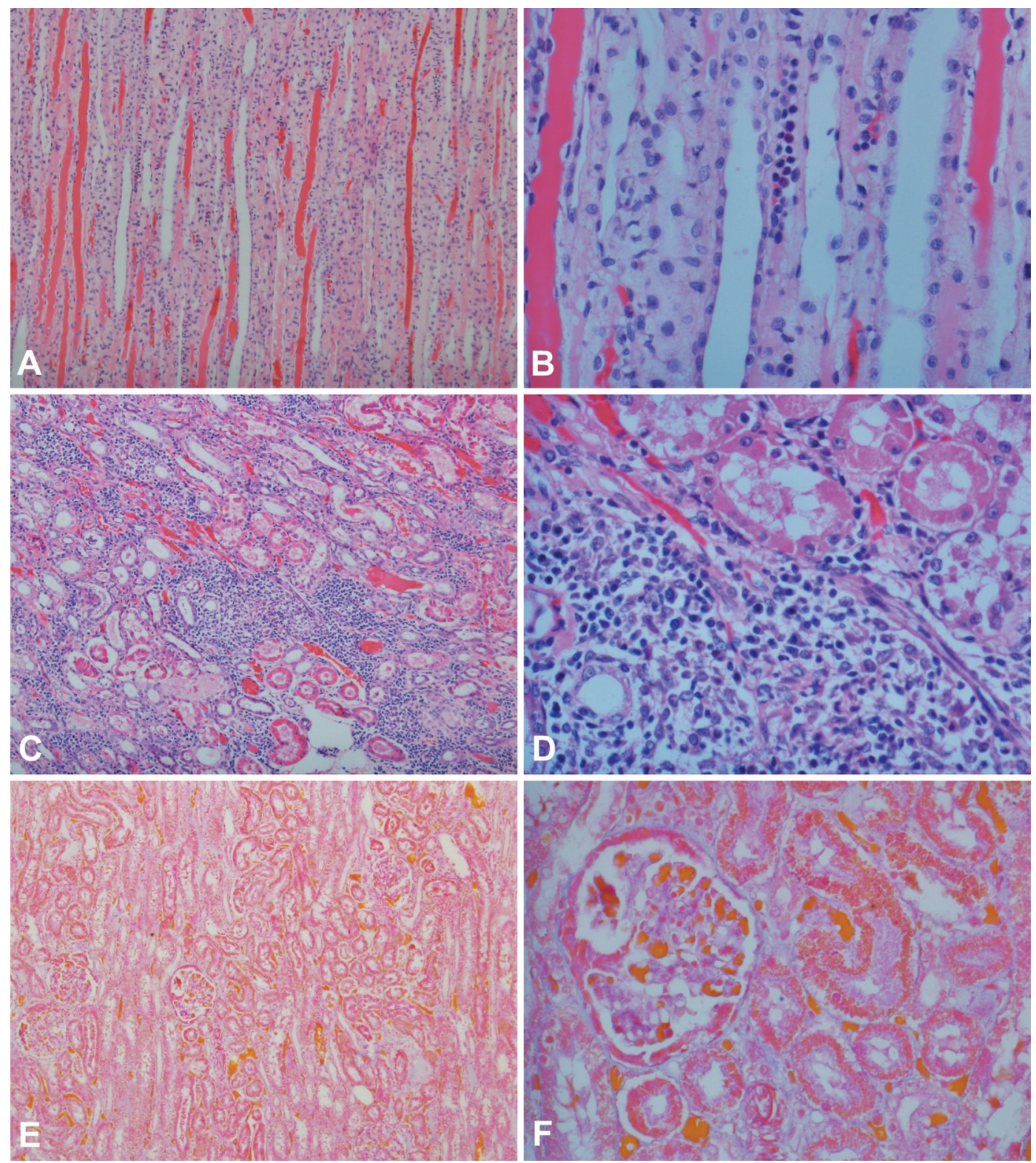

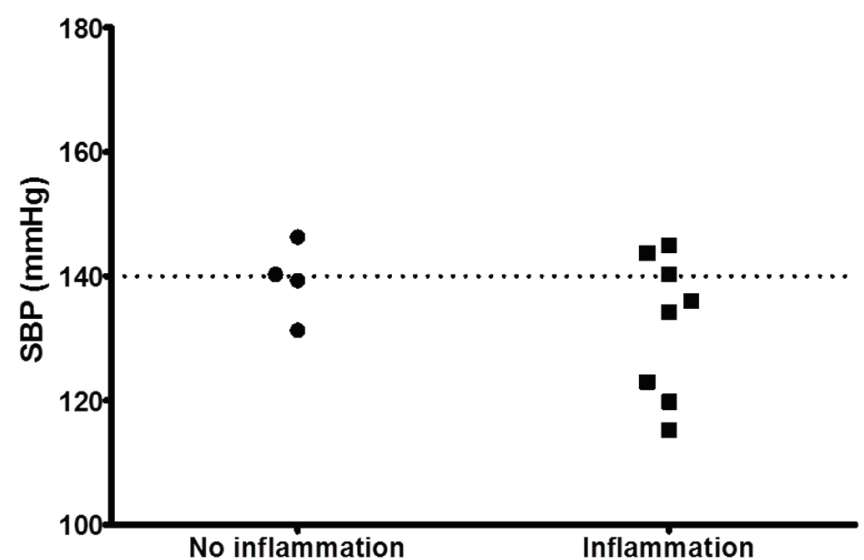

Fig.2. Systolic blood pressure in dogs with naturally-occurring visceral leishmaniasis $(n=12)$ subdivided in accordance with the documentation of renal inflammation on histopathology. The dotted line represents the cut-off value used for the diagnosis of hypertension in this investigation. observed in $16.7 \%(2 / 12)$ of the samples. Interestingly, no association was documented $(\mathrm{P}=0.6788)$ between hypertension and the identification of inflammation on histopathology when SAP $>140 \mathrm{mmHg}$ was considered as a diagnostic cut-off for systemic hypertension (Fig.2). Also, anti-Leishmania immunohistochemistry assays stained the renal epithelium in only $16.7 \%(2 / 12)$ of the animals (Fig.3).

\section{DISCUSSION}

Data concerning the prevalence of systemic hypertension in dogs is still conflicting. However, it is known that renal disease, which may be documented in 50 to $93 \%$ of hypertensive dogs, is the condition most commonly associated with it in small animal practice (Snyder 1991). Interestingly, renal injury is likely to be the single most frequent consequence in dogs with visceral leishmaniasis, leading to mild proteinuria, nephrotic syndrome, and eventually progressing up to the stage of renal failure, which is recog- 


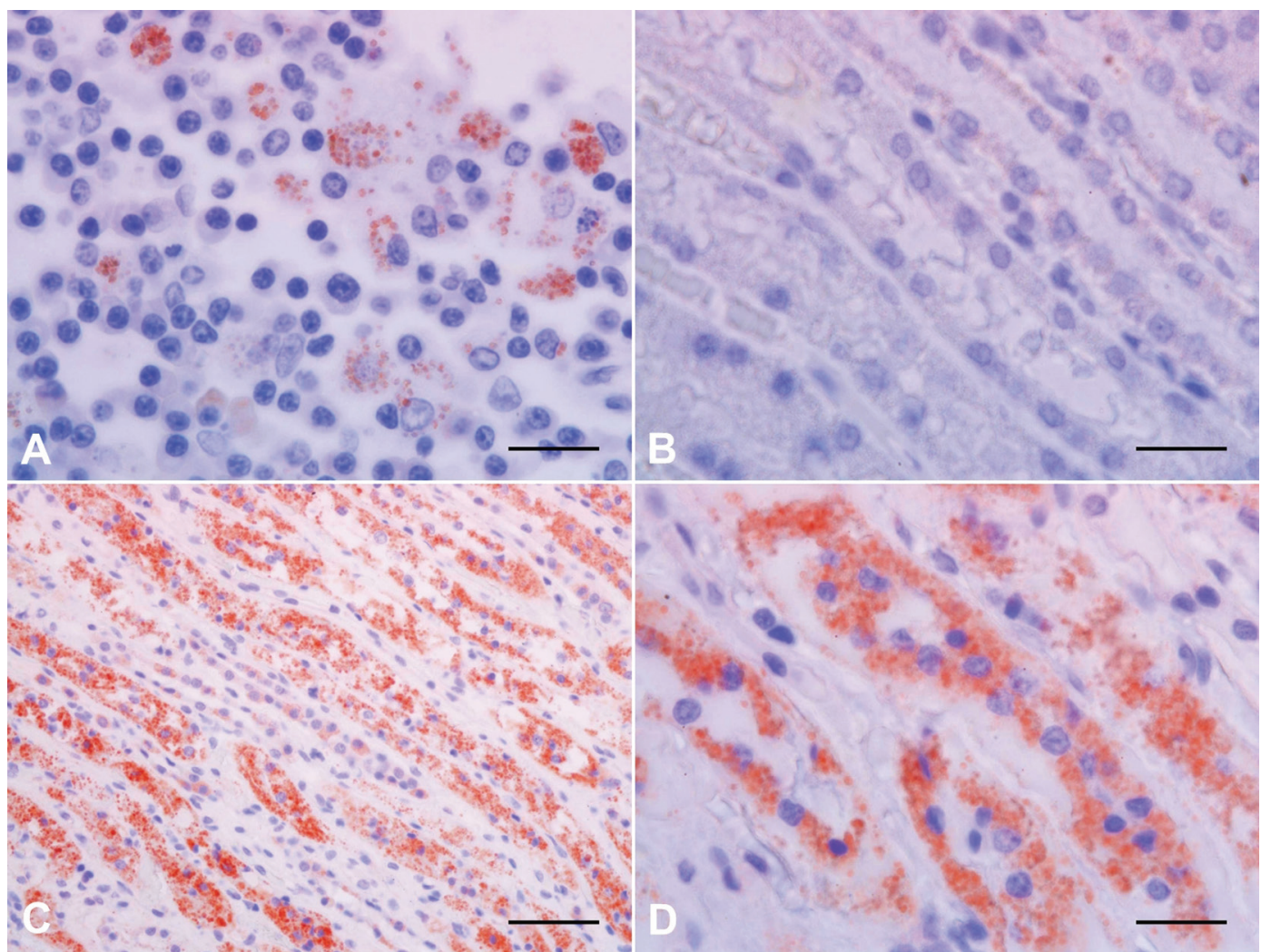

Fig.3. Anti-Leishmania immunohistochemistry (streptavidin-peroxidase complex; AEC chromogen, hematoxylin counterstain). (A) Positive staining in a lymph node sample used as control. Obj.100x. (B) Kidney negative staining. Obj.100x. (C) Kidney tissue sample (Obj.40x) showing positive staining within the renal tubular epithelial cells. (D) Detail of the positive staining within the cytoplasm of tubular epithelial cells. Obj.100x.

nized as an important cause of death among infected dogs (Solano-Gallego et al. 2009).

Systemic arterial hypertension is defined as a sustained increase in blood pressure (Brown et al. 2007). While it is true that different cut-offs exist for what is considered an increase in blood pressure, it is also true that these cut-offs are dependent on what is accepted as the normal reference range for systemic arterial pressure. In this investigation, any dog with a SAP $>140 \mathrm{mmHg}$ was classified as hypertensive in consideration of prior studies that investigated the normal systolic arterial pressure using an oscillometric device in conscious dogs. A study by Bodey \& Michell (1992) evaluated 1,782 healthy dogs and found a mean SAP of $133.00 \pm 20.68 \mathrm{mmHg}$, which translates into a $95 \%$ confidence interval of 132.04 to $133.96 \mathrm{mmHg}$. In another study that included 102 conscious healthy dogs, a mean SAP of $118.60 \pm 18.7 \mathrm{mmHg}$ was documented, resulting in a $95 \%$ CI that varies from 114.97 to $122.23 \mathrm{mmHg}$ (Mishina et al. 1997).

To the best of the authors' knowledge, Cortadellas et al. (2006) performed the first study which investigated the prevalence of systemic arterial hypertension in dogs with visceral leishmaniasis. They documented 49.5\% (52/105) of renal disease with elevated serum creatinine and UPC, as well as $30.5 \%(32 / 105)$ of hypertensive animals, which is a little lower than the $38.9 \%$ of hypertensive dogs observed in this study. Contrasting with our results, they also found $2.8 \%(3 / 105)$ of the animals with increased arterial pressure without evidence of renal injury, while our data indicated $5.5 \%(1 / 18)$ of the dogs without any laboratory clue of renal injury, including normal serum creatinine concentration, and UPC, as well as the USG within the normal range, despite being hypertensive. Unfortunately, their study did not provide a histopathological assessment of the kidneys, so that any association between hypertension and renal injuries could be anticipated. Another study by Cortadellas et al. (2008) investigating 26 dogs with visceral leishmaniasis and microalbuminuria, an early surrogate of glomerular lesion, documented $34.7 \%(9 / 26)$ of hypertension, which is also similar to our results, but contrasted with a very recent study, in which only $8.8 \%$ of Leishmania spp. infected dogs were diagnosed with systemic arterial hypertension, even though an UPC $>0.5$ were identified in 83.3\% of them (Braga et al. 2015).

Although the studies by Cortadellas et al (2006) and Cortadellas et al (2008) classified the animals as hypertensive only when documenting either a SAP $\geq 180 \mathrm{mmHg}$ or a SAP between 150 and $179 \mathrm{mmHg}$ with overt clinical manifestations attributable to systemic hypertension, and Braga et al (2015) considered a SAP cut-off of $\geq 160 \mathrm{mmHg}$, the consensus statement on systemic hypertension in small animals defined such condition as a sustained increase in blood pressure, even though target organ lesions, including the reduction in glomerular filtration rate, ocular lesions, and hypertensive encephalopathy, are only likely to occur when a SAP $>160 \mathrm{mmHg}$ is identified (Brown et al 
2007). Actually, some dogs recruited for this investigation were classified as hypertensive because the SAP was greater than the normal reference range proposed by two large systematic investigations (Bodey \& Michell 1992, Mishina et al. 1997), but the majority of these animals were undoubtedly at minimal to mild risk of target organ damage. Therefore, if the cut-off for systemic hypertension in this study was increased to $160 \mathrm{mmHg}$, no dog would be considered hypertensive, even though renal lesions documented on histopathology would still be a concern.

Because creatinine is completely excreted by the glomeruli, it is used as an indicator of glomerular filtration (Sousa et al. 2011). However, it is well known that it only accumulates in blood with a severe compromise of renal function, which minimizes its role as a surrogate for renal function in the early stages of the disease. Although several studies documented azotemia in dogs with visceral leishmaniasis (Nieto et al. 1992, Ciaramella et al. 1997, Moura et al. 2002, Sousa et al. 2011), the majority of the dogs (13/18) reported here had serum creatinine within the normal limits, despite the means listed in Table 1 point towards the deterioration of renal function as the clinical scenario worsens. Nonetheless, a study by Nieto et al. (1992) found elevated serum creatinine in $30 \%$ of the infected animals, which is similar to the $27.8 \%$ of azotemic dogs in this investigation.

On the other hand, more sensible tests, such as the UPC, and the FE of $\mathrm{Na}^{+}$, increased in accordance with the severity of clinical status. Dogs with a preserved tubular function have the $\mathrm{FE}$ of $\mathrm{Na}^{+}$and $\mathrm{K}^{+}<1 \%$ and $<24 \%$, respectively, while in dogs with a normal glomerular function the typical UPC will be $<0.5$ (Dibartola 2000, Santin et al. 2006, Grauer 2011). The majority of the animals enrolled in this investigation showed an increased UPC $(>0.5)$, and fraction excretion of sodium $(>1 \%)$, which likely indicate the compromise to the glomeruli and tubules attributable to visceral leishmaniasis (Costa et al. 2003, Baneth et al. 2008) in spite of renal failure being absent.

The histological analyses performed in this study are supportive of renal inflammatory lesions, since lymphoplasmacytic and histiocytic infiltrates, as well as multifocal degeneration were identified. A recent study showed interstitial nephritis with a lymphoplasmacytic infiltrate in $70.6 \%(48 / 68)$ of the infected animals. However, membranoproliferative glomerulonephritis (39/68), glomerular fibrosis (30/68), membranous glomerulonephritis (22/68), and hyaline casts $(39 / 68)$ were also identified (Braga et al. 2015). In dogs with leishmaniasis, glomerulonephritis and tubulointerstitial nephritis are the most common renal pathologic findings, whereas amyloidosis is considered rare (Lopez et al. 1996, Costa et al. 2003, Zatelli et al. 2003). Glomerulonephritis is commonly ascribed to the deposition of immune complexes, with either the membranoproliferative or mesangioproliferative forms being most frequently associated with chronic renal failure. Mesangioproliferative lesions and glomerulonephritis with minimal alterations are normally documented in dogs with no clinicopathological evidence of renal disease (Costa et al. 2003, Zatelli et al. 2003, Plevraki et al. 2006). Although not investigated herein, previous studies demonstrated that the infiltration of $\mathrm{CD} 4^{+} \mathrm{T}$ cells at both the glomerular and interstitial areas of the kidneys also play a role in the development of renal disease in dogs naturally-infected with Leishmania chagasi (Costa et al. 2000, 2010).

Even though the majority of the animals presented at least one laboratory evidence of renal injury, the small population recruited into this investigation represents a big limitation for the reliability of our data regarding the association of renal lesions and the development of arterial hypertension in Leishmania spp. infected dogs. Also, the absence of a more detailed immunohistochemical analysis did not allow the identification of the cell population infiltrating the renal tissue. Finally, even though other studies have chosen higher cut-off values to differentiate hypertensive and non-hypertensive dogs, for the purpose of this investigation we considered any dog with a systolic arterial pressure $>140 \mathrm{mmHg}$ as hypertensive. Therefore, caution must be exercised since several factors could interfere with blood pressure measurement, including what is known as white coat syndrome, as well as the operator experience and the pressure equipment itself. This might explain the varying pressure values and prevalences of arterial hypertension reported for dogs with leishmaniasis in the literature.

\section{CONCLUSIONS}

Mild systemic arterial hypertension was identified in a small subset of animals.

No relationship between the severity of clinical signs and hypertension could be documented.

The role played by renal injury attributed to Leishmania spp. in systemic hypertension is not completely clear and further studies with a larger population of affected animals are warranted to clarify this condition.

Acknowledgements.- The authors thank Conselho Nacional de Desenvolvimento Científico e Tecnológico (CNPq) for the financial support of this study.

Conflict of interest statement.- The authors have no competing interests.

\section{REFERENCES}

Baneth G., Koutinas A.F., Solano-Gallego L., Bourdeau P. \& Ferrer L. 2008. Canine leishmaniosis: new concepts and insights on an expanding zoonosis: part one. Trends Parasitol. 24:324-330.

Bodey A.R. \& Michell A.R. 1996. Epidemiological study of blood pressure in domestic dogs. J. Small Anim. Pract. 37:116-125.

Braga E.T., Leite J.H.A.C., Rosa F.A., Tivelli P., Araújo A.M., Almeida B.F.M., Ferrari H.F., Ciarlini P.C., Machado G.F. \& Marcondes M. 2015. Hypertension and its correlation with renal lesions in dogs with leishmaniosis. Revta Bras. Parasitol. Vet. 24:45-51.

Brown S., Atkins C., Bagley R., Carr A., Cowgill L., Davidson M., Egner B., Elliott J., Henik R., Labato M., Littman M., Polzin D., Ross L., Snyder P. \& Stepien R. 2007. Guidelines for the identification, evaluation, and management of systemic hypertension in dogs and cats. J. Vet. Intern. Med. 21:542-558.

Ciaramella P., Oliva G., Luna R.D., Gradoni L., Ambrosio R., Cortese L., Scalone A. \& Persechino A. 1997. A retrospective clinical study of canine leishmaniosis in 150 dogs naturally infected by Leishmania infantum. Vet. Rec. 141:539-543.

Cortadellas O., Del-Palacio M.J., Bayón A., Albert A. \& Talavera J. 2006. Systemic hypertension in dogs with leishmaniasis: prevalence and clinical consequences. J. Vet. Intern. Med. 20:941-947. 
Cortadellas O., Del-Palacio M.J., Talavera J. \& Bayón A. 2008. Glomerular filtration rate in dogs with leishmaniasis and chronic kidney disease. J. Vet. Intern. Med. 22:293-300.

Costa F.A.L., Guerra J.L., Silva S.M., Klein R.P., Mendonça I.L. \& Goto H. 2000. CD4+ T cells participate in the nephropathy of canine visceral leishmaniasis. Braz. J. Med. Biol. Res. 33:1455-1458.

Costa F.A.L., Goto H., Saldanha L.C.B., Silva S.M., Sinhorini I.L., Silva T.C. \& Guerra J.L. 2003. Histopathologic patterns of nephropathy in naturally acquired canine visceral leishmaniasis. Vet. Pathol. 40:677-684.

Costa F.A.L., Prianti M.G., Silva T.C., Silva S.M., Guerra J.L. \& Goto H. 2010. T cells, adhesion molecules and modulation of apoptosis in visceral leishmaniasis glomerulonephritis. BMC InfectBa. Dis. 10:112.

Dibartola S.P. 2000. Clinical approach and laboratory evaluation of renal disease, p.1600-1614. In: Ettinger S.J. \& Feldman E.C. (Eds), Textbook of Veterinary Internal Medicine. 5th ed. W.B. Saunders, Philadelphia.

Dukes J. 1992. Hypertension: a review of the mechanisms, manifestations and management. J. Small Anim. Pract. 33:119-129.

Grauer G.F. 2011. Proteinuria: measurement and interpretation. Top. Companion Anim. Med. 4:121-127.

Koutinas A.F., Polizopoulou Z.S., Saridomichelakis M.N., Argyriadis D., Fytianou A. \& Plevraki K.G. 1999. Clinical considerations on canine visceral leishmaniasis in Greece: a retrospective study of 158 cases (19891996). J. Am. Anim. Hosp. Assoc. 35:376-383.

Krieger E.M., Franchini K.G. \& Krieger J.E. 1996. Fisiopatogenia da hipertensão arterial. Medicina, Ribeirão Preto, 29:181-192.

Lopez R., Lucena R., Novales M., Ginel P.J., Martin E. \& Molleda J.M. 1996. Circulating immune complexes and renal function in canine leishmaniasis. J. Vet. Med. 43:469-474.

Mishina M., Watanabe T., Fujii K., Maeda H., Wakao Y. \& Takahashi M. 1997. Clinical evaluation of blood pressure through non-invasive measurement using the oscillometric procedure in conscious dogs. J. Vet. Med. Sci. 59:989-993.

Moura R.O.D., Paula V.V. \& Soares M.J.V. 2002. Alterações renais em cães
(Canis familiaris) soropositivos para leishmaniose: aspectos clínicos, laboratoriais e histopatológicos. Revta Bras. Med. Vet. 4:61-64.

Nieto C.G., Navarrete I., Habela M.A., Serrano F. \& Redondo E. 1992. Pathological changes in kidneys of dogs with natural Leishmania infection. Vet. Parasitol. 45:33-47.

Plevraki K., Koutinas A.F., Kaldrymidou H., Roumpies N., Papazoglou L.G., Saridomichelakis M.N., Savvas I. \& Leondides L. 2006. Effects of allopurinol treatment on the progression of chronic nephritis in canine leishmaniosis (Leishmania infantum). J. Vet. Intern. Med. 20:228-233.

Santin F., Moutinho F.Q., Amaral A.S. \& Takahira R.K. 2006. Acompanhamento laboratorial da função renal de cães sadios tratados experimentalmente com doses terapêuticas de anfotericina B. Ciência Rural 36:1816-1823.

Snyder P.S. 1991. Canine hypertensive disease. Compend. Cont. Educ. Pract. Vet. 13:1785-1793.

Solano-Gallego L., Fernández-Bellon H., Morell P., Fondevila D., Alberola J., Ramis A. \&Ferrer L. 2004. Histological and immunohistochemical study of clinically normal skin of Leishmania infantum-infected dogs. J. Comp. Pathol. 130:7-12.

Solano-Gallego L., Koutinas A., Miró G., Cardoso L., Pennisi M.G., Ferrer L., Bourdeau P., Oliva G. \& Baneth G. 2009. Directions for the diagnosis, clinical staging, treatment and prevention of canine leishmaniosis. Vet. Parasitol. 165:1-18.

Sousa M.V.C., Castro I.P. \& Magalhães G.M. 2011. Níveis séricos de uréia e creatinina em cães naturalmente infectados por Leishmania chagasi. Disponível em <http://www.pubvet.com.br/imagens/artigos/ 552011-103547-sousa1078.pdf> Acessado em 28 jan. 2015.

Tarufi W.L., Santos R.D.L., Arantes R.M.E., Gonçalves R., De Melo M.N., Michalick M.S. \& Tafuri W.L. 2004. An alternative immunohistochemical method for detecting Leishmania amastigotes in paraffin-embedded canine tissues. J. Immunol. Methods 292:17-23.

Zatelli A., Borgarelli M., Santilli R., Bonfanti U., Nigrisoli E., Zanatta R., Tarducci A. \& Guarraci A. 2003. Glomerular lesions in dogs infected with Leishmania organisms. Am. J. Vet. Res. 64:558-561. 